\title{
EFFECT OF DIAMETER OF THE COTTON SQUARES IN THE DEVELOPMENT OF BOLL WEEVIL (1)
}

\author{
MARCOS DONISETI MICHELOTTO $\left({ }^{2}\right)$; NORTON RODRIGUES CHAGAS FILHO $\left({ }^{3}\right)$; \\ RICARDO ADAIME DA SILVA $\left({ }^{4}\right)$; ANTONIO CARLOS BUSOLI $\left({ }^{1}\right)$
}

\begin{abstract}
The objective of this work was to study the effect of diameter of the cotton squares in the corporal mass of adults of boll weevil, Anthonomus grandis Boheman (Coleoptera: Curculionidae). The assay was carried out under field and laboratory conditions, in Jaboticabal, São Paulo State, Brazil. Six samplings obtained from a random harvesting of ten plants of each cultivar (Coodetec 405 and Fibermax 986). The number and diameter of squares were recorded for each plant. Squares with oviposition orifices were kept individually in a recipient and observed daily until adult emergence. The larger the diameter of the squares, the more corporal mass of boll weevil newly emerged adults in both cultivars.
\end{abstract}

Key words: Insecta, Curculionidae, Anthonomus grandis, Gossypium hirsutum.

\section{RESUMO}

\section{EFEITO DO DIÂMETRO DO BOTÃO FLORAL NO DESENVOLVIMENTO DO BICUDO-DO-ALGODOEIRO}

\begin{abstract}
O objetivo deste trabalho foi estudar o efeito do diâmetro dos botões florais de algodoeiro na massa corporal de adultos do bicudo-do-algodoeiro, Anthonomus grandis Boheman (Coleoptera: Curculionidae). O experimento foi realizado em condições de campo e laboratório, em Jaboticabal (SP), Brasil. Foram realizadas seis amostragens, coletando-se ao acaso dez plantas nas cultivares Coodetec 405 e Fibermax 986, avaliando-se o número e o diâmetro de botões florais. Os botões florais com orifícios de oviposição foram individualizados em frascos e observados diariamente para a visualização da emergência dos adultos. Botões florais com maiores diâmetros proporcionam maior massa corporal de adultos de $A$. grandis recém-emergidos nas duas cultivares.
\end{abstract}

Palavras-chave: Insecta, Curculionidae, Anthonomus grandis, Gossypium hirsutum.

( $\left.{ }^{1}\right)$ Recebido para publicação em 24 de fevereiro de 2005 e aceito em 14 de setembro de 2006.

$\left({ }^{2}\right)$ Agência Paulista de Tecnologia dos Agronegócios, Pólo Regional do Centro Norte (APTA Centro-Norte), Rodovia Washington Luiz, km 372, Caixa Postal 24, 15830-000 Pindorama (SP), Brasil. E-mail: michelotto@aptaregional.sp.gov.br

$\left({ }^{3}\right)$ Aluno do Programa de Pós-graduação em Entomologia Agrícola, Faculdade de Ciências Agrárias e Veterinárias da Universidade Estadual Paulista (FCAV/UNESP), Via de Acesso Prof. Paulo Donato Castellane, s/n, 14884-900 Jaboticabal (SP), Brasil. E-mail: nortonrc@fcav.unesp.br

$\left({ }^{4}\right)$ Embrapa Amapá, Rodovia JK, km 5, 68903-000 Macapá (AP), Brasil. E-mail: adaime@cpafap.embrapa.br

$\left({ }^{5}\right)$ Departamento de Fitossanidade, Faculdade de Ciências Agrárias e Veterinárias da Universidade Estadual Paulista (FCAV/UNESP), Jaboticabal (SP). E-mail: acbusoli@fcav.unesp.br. 


\section{INTRODUCTION}

The boll weevil, Anthonomus grandis Boheman (Coleoptera: Curculionidae) is one of the most important pests of the cotton (Gossypium hirsutum L.) crop because of the damage it causes (CARVAlHo et al., 1996). According to Busoli (1991), the boll weevil is a key pest, being widespread all over the American Continent. Yet according to this author, when adequate cultural practices like following the regular planting season and destroying the stalk are not adopted, the damage caused by this insect can be severe.

Females of $A$. grandis select squares bigger than $6 \mathrm{~mm}$ in diameter to perform its postures, especially the ones in the upper third of the plant (Sterling and AdKinnson, 1971; Ramalho and Jesus, 1988 and SoAres et al., 1999). According to Ramiro et al. (1992), attacked squares have orifices of approximately $1 \mathrm{~mm}$ in diameter, usually with a yellow ring around formed by pollen grains. On the other hand, the squares used for oviposition are characterized by the presence of wax sealing the hole dug by the female.

The attack of $A$. grandis generally occurs in squares but when they are not present and there is a high population density of adults, up to $50 \%$ of the bolls can be attacked (Michelotto et al., 2003). Busoli et al. (2004) observed that the boll weevil prefers bolls up to 2 days old (smaller diameter), instead of older bolls ( 8 and 12 days old).

Although there are many studies about the oviposition preference of $A$. grandis, it is unknown if the age and consequently the diameter of the squares influence the development of larvae producing adults with higher corporal mass. This research was conducted to observe phenologycal aspects of flowering and boll development of two cotton cultivars and their influence on the development and corporal mass of $A$. grandis adults.

\section{MATERIAL AND METHODS}

The research was carried out under field and laboratory conditions, in Jaboticabal, São Paulo State, Brazil. On December $6^{\text {th }}, 2002$, the cotton cultivars Coodetec 405 and Fibermax 986 were soughed in an area of $500 \mathrm{~m}^{2}$ each. Crop recommendations were all followed but without using insecticides and growth regulators. Six evaluations were performed when the flowering and boll development started, at $45,51,58$, 66,80 and 98 days after the emergence (DAE), collecting 10 plants/cultivar at random. At the laboratory, the number of cotton squares and bolls was counted and their diameters were measured. The squares were carefully examined for $A$. grandis oviposition orifices.

Cotton squares with oviposition orifices were kept individually in photographic film containers (3 $\mathrm{cm}$ in diameter, $5 \mathrm{~cm}$ high), with a hole in the lid (2 $\mathrm{cm}$ in diameter) covered by a quadrangular piece of "voiale". These containers were observed daily, and the newly emerged adults (up to 24 hours) were individually weighed in an electronic precision scale.

The numbers of squares and their respective diameters in two cotton cultivars were examined with analyses of variance (ANOVA) using Stat program. The numbers of squares were $(x+0.5)^{1 / 2}$ transformed before statistical analysis, but results are presented as non transformed means. Where significant $\mathrm{F}$ values were obtained, means were separated using Tukey test $(a ́=0.05)$.

For characterization of the relation between the corporal mass of the adults of boll weevil and the respective diameters of cotton squares in the two cultivars, were carried through an analysis of polynomial regression, determining the curves more adjusted and the respective coefficients of determination $\left(R^{2}\right)$. The corporal mass of 39 and 37 adults and the respective diameters of the squares in the Coodetec 405 and Fibermax 986, respectively, were measured. The diameters were grouped in 7 classes in accordance with the formula of Yule (SAMPAIO, 1998).

\section{RESULTS AND DISCUSSION}

The number of cotton squares per plant in Coodetec 405 cultivar was higher that cotton squares in Fibermax 986 lonely at 45 DAE (Table 1). The production of cotton squares by plant in two cotton cultivars increased until $80 \mathrm{DAE}$, reaching 16.3 and 17.0 squares per plant in Fibermax 986 and Coodetec 405, respectively (Table 1). This number decreased drastically in the last evaluation at $98 \mathrm{DAE}$, with an average of 2.6 squares per plant in Coodetec 405 and 2.7 in Fibermax 986 (Table 1), due to the characteristics of each cultivar and probably to the high rate of $A$. grandis attack. These results are similar to those observed by LOPES (1994), who found a square production peak at $81 \mathrm{DAE}$ in the cotton cultivar IAC-20, without application of plant growth regulators.

The diameter of the squares varied from 4.44 to $6.62 \mathrm{~mm}$ (Fibermax 986) and 5.45 to 7,52 $\mathrm{mm}$ (Coodetec 405) (Table 1). In the evaluations at 45, 58 and $66 \mathrm{DAE}$, the diameters of squares were higher in Coodetec 405 . At 80 DAE the diameter of squares was higher in Fibermax 986 (Table 1). The production of squares and bolls 
depends on many crop factors. However, the early planting recommendation results in earlier square production (until the middle of January in São Paulo State), occurring phenology asynchronism (host evasion) in relation to the high infestations of boll weevil from the second and third adult generations (BUSOLI, 1991). SOARES and ARAúJo (1993) compared three times of cotton sowing and observed that the number of bolls decreased to 12 per plant in October, 3 in November, and in December no boll was produced due to boll weevil attack.

Table 1. Number mean $( \pm$ SE) and diameter $(\mathrm{mm})$ mean $( \pm \mathrm{SE})$ of cotton squares by plant in Coodetec 405 and Fibermax 986 cotton cultivars. Jaboticabal, SP, 2003

\begin{tabular}{|c|c|c|c|c|c|c|}
\hline \multirow{2}{*}{ Valuation Date } & \multirow{2}{*}{ DAE } & \multirow{2}{*}{ Squares } & \multicolumn{2}{|c|}{ Cultivar } & \multirow{2}{*}{ Test F } & \multirow{2}{*}{ C.V. $(\%)$} \\
\hline & & & Coodetec 405 & Fibermax 986 & & \\
\hline 24/January & 45 & $\begin{array}{l}\text { Number } \\
\text { Diameter }\end{array}$ & $\begin{array}{l}8.70 \pm 0.62 \mathrm{a} \\
5.76 \pm 0.16 \mathrm{a}\end{array}$ & $\begin{array}{l}5.60 \pm 0.95 \mathrm{~b} \\
4.44 \pm 0.19 \mathrm{~b}\end{array}$ & $\begin{array}{r}8.54^{* *} \\
28.57^{* *}\end{array}$ & $\begin{array}{l}17.09 \\
10.83\end{array}$ \\
\hline 30/ January & 51 & $\begin{array}{l}\text { Number } \\
\text { Diameter }\end{array}$ & $\begin{array}{l}9.80 \pm 0.83 \mathrm{a} \\
5.45 \pm 0.20 \mathrm{a}\end{array}$ & $\begin{array}{r}10.20 \pm 1.08 \mathrm{a} \\
5.10 \pm 0.18 \mathrm{a}\end{array}$ & $\begin{array}{l}0.05^{\mathrm{ns}} \\
1.62^{\mathrm{ns}}\end{array}$ & $\begin{array}{l}14.96 \\
11.64\end{array}$ \\
\hline 06/February & 58 & $\begin{array}{l}\text { Number } \\
\text { Diameter }\end{array}$ & $\begin{array}{r}13.50 \pm 1.19 \mathrm{a} \\
6.85 \pm 0.21 \mathrm{a}\end{array}$ & $\begin{array}{r}11.60 \pm 1.24 \mathrm{a} \\
6.03 \pm 0.12 \mathrm{~b}\end{array}$ & $\begin{array}{r}1.29^{\mathrm{ns}} \\
10.91^{* *}\end{array}$ & $\begin{array}{r}15.12 \\
8.62\end{array}$ \\
\hline 14/ February & 66 & $\begin{array}{l}\text { Number } \\
\text { Diameter }\end{array}$ & $\begin{array}{r}16.20 \pm 1.40 \mathrm{a} \\
6.28 \pm 0.22 \mathrm{a}\end{array}$ & $\begin{array}{r}14.30 \pm 1.14 \mathrm{a} \\
5.55 \pm 0.19 \mathrm{~b}\end{array}$ & $\begin{array}{l}1.05^{\mathrm{ns}} \\
6.45^{*}\end{array}$ & $\begin{array}{l}12.88 \\
10.87\end{array}$ \\
\hline 28/ February & 80 & $\begin{array}{l}\text { Number } \\
\text { Diameter }\end{array}$ & $\begin{array}{r}17.00 \pm 1.13 \mathrm{a} \\
6.10 \pm 0.10 \mathrm{~b}\end{array}$ & $\begin{array}{r}16.30 \pm 1.33 \mathrm{a} \\
6.59 \pm 0.16 \mathrm{a}\end{array}$ & $\begin{array}{l}0.19^{\mathrm{ns}} \\
6.95^{*}\end{array}$ & $\begin{array}{r}11.69 \\
6.55\end{array}$ \\
\hline 18/March & 98 & $\begin{array}{l}\text { Number } \\
\text { Diameter }\end{array}$ & $\begin{array}{l}2.60 \pm 0.50 \mathrm{a} \\
7.52 \pm 0.38 \mathrm{a}\end{array}$ & $\begin{array}{l}2.70 \pm 0.58 \mathrm{a} \\
6.62 \pm 0.25 \mathrm{a}\end{array}$ & $\begin{array}{l}0.02^{\mathrm{ns}} \\
3.81^{\mathrm{ns}}\end{array}$ & $\begin{array}{l}31.68 \\
13.80\end{array}$ \\
\hline
\end{tabular}

DAE $=$ Days after emergency.

Means ( \pm SE) followed by the same letter in the line are not significantly different by Tukey test. ${ }^{\mathrm{ns}}=$ non-significant; ${ }^{*}=$ significant at $5 \%$ of probability; ${ }^{* *}=$ significant at $1 \%$ of probability.
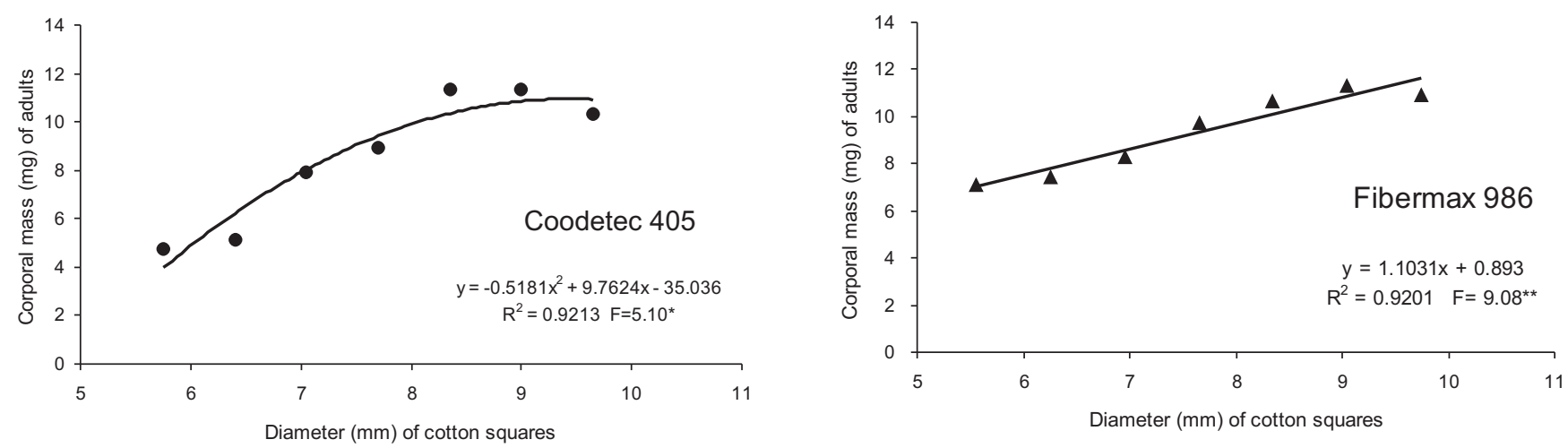

Figure 1. Adjusted curve for the polynomial regression between diameter ( $\mathrm{mm}$ ) of cotton squares with orifices of oviposition and corporal mass (mg) of the boll weevil adults, in Coodetec 405 and Fibermax 986 cultivars. Jaboticabal, SP. 2003. * ${ }^{*}$ significant from $5 \%$ of probability; ${ }^{* *}=$ significantly from $1 \%$ of probability.

Of all squares with oviposition orifices, $60 \%$ and $68 \%$ had diameters between 6 and $8 \mathrm{~mm}$ in Coodetec 405 and Fibermax 986, respectively, which is in accordance with Lloyd et al. (1961) and RAMALHO and Jesus (1988), who found that the boll weevil prefers squares bigger than $6 \mathrm{~mm}$ in diameter so that larvae have enough food to develop and become adults.

The level of control for the boll weevil proposed by Busoli (1991) and validated by GIELFI and Busoli (1998) of $10 \%$ of attacked squares, was not reached until $58 \mathrm{DAE}$, with an average of $8.8 \%$ of attacked squares in Fibermax 986, and 66 DAE in Coodetec 405 , with $1.2 \%$ of attacked squares. At the last evaluation (98 DAE), the cultivar Fibermax 986 had $74.1 \%$ of attacked squares, while in Coodetec 405 this rate was even higher (84.6\%). However, as to the 98 DAE the majority of bolls were already formed, the number of floral buttons is low, and any attacked represents high percentage. Morales et al. (1997) observed that the percentage of boll weevil attacked squares varied from $4.6 \%$ in Sicot 3 (resistant genotype with frego-type bract) to $48.1 \%$ in the cultivar IAC-20 (susceptible), evidencing the difference between these genotypes in terms of boll weevil resistance. 
The curve more adjusted for the polynomial regression between the diameter of cotton squares (Coodetec 405 cultivar) and the corporal mass followed the quadratic model (Figure 1). The mean corporal mass of adults of boll weevil increased with the increased of diameter of squares, probability by higher food availability. In Fibermax 986 cultivar, the curve followed the linear model (Figure 1), where squares with greater diameter result in emerged adults of boll weevil with higher corporal mass.

The results showed that both cultivars, squares with greater diameter result in emerged adults of boll weevil with higher corporal mass.

\section{REFERENCES}

BUSOLI, A.C. Práticas culturais, reguladores de crescimento, controle químico e feromônios no manejo integrado de pragas do algodoeiro. In: DEGRANDE, P.E. Bicudo do algodoeiro: Manejo Integrado. Dourados: UFMS/EMBRAPA, 1991. p.29-52.

BUSOLI, A.C.; PEREIRA, F.F.; LOPEZ; V.A.G.;SOARES, J.J.;MELO, R.S.; ALMEIDA, C.A. Preferência alimentar do bicudo-doalgodoeiro por frutos de diferentes cultivares e idades. Pesquisa Agropecuária Brasileira, Brasília, v.39, n.2, p.101-104, 2004.

CARVALHO, L.P.; LUKEFHAR, M.J.; FARIAS, F.J.C.; VIEIRA, R.M.; MOREIRA, J.A.N.; COSTA, J.N. Seleção de algodoeiro com resistência ao bicudo. Pesquisa Agropecuária Brasileira, Brasília, v.31, n.3, p.195-199, 1996.

GIELFI, F.S.; BUSOLI, A.C. Níveis de danos de Anthonomus grandis Boheman, 1843 (Coleoptera: Curculionidae) e produtividade do algodão (Gossypium hirsutum L.) cv. IAC-20. In: CONGRESSO BRASILEIRO DE ENTOMOLOGIA, 17., 1998, Rio de Janeiro. Resumos... Rio de Janeiro: UFRJ/SEB, 1998. p.139.

LLOYD, E.P.; MCMEANS, J.J.; MERKL, M.E. Prefered feeding and egg laying sites of the boll weevil and the effect of weevil damage on the cotton plant. Journal of Economic Entomology, Lanham, v.54, n.5, p.979-987, 1961.

LOPES, V.A.G. Características fenológicas de cultivares de algodoeiro Gossypium hirsutum L. e ataque de pragas, especialmente o bicudo-do-algododeiro, Anthonomus grandis Boheman, 1843 (Coleoptera: Curculionidae). 1994. 111p. Dissertação (Mestrado em Entomologia Agrícola) - Faculdade de Ciências Agrárias e Veterinárias, UNESP, Jaboticabal.
MICHELOTTO, M.D.; SILVA, R.A.; CHAGAS FILHO, N.R.; BUSOLI, A.C. Ocorrência simultânea de Anthonomus grandis Boheman, 1843 (Coleoptera: Curculionidae) e Pectinophora gossypiella (Saunders, 1844) (Lepidoptera: Gelechiidae) em maçãs de seis cultivares de algodoeiro. In: CONGRESSO BRASILEIRO DE ALGODÃ̃O, 4., 2003, Goiânia. Resumos...Goiânia: Embrapa/UFG, 2003. 4p. [CD ROM]

MORALES, L.; CENA, P.; MENDES NETO, F.P.; COSTA, S.F.; OLIVEIRA, F.T. Resistência de genótipos de algodoeiro a Anthonomus grandis Boh., Frankliniella sp. e Aphis gossypii Glover. Anais da Sociedade Entomológica do Brasil, Londrina, v.26, n.1, p.93-97, 1997.

RAMALHO, F.S.; JESUS, F.M.M. Distribution of boll weevil (Anthonomus grandis) eggs within cotton squares. Tropical Agriculture, Trinidad and Tobago, v.65, n.3, p.245-248, 1988.

RAMIRO, Z.A.; NETTO, N.D.; NOVO, J.P.S.; PURGATO, G.L.S.; CORREIA, M.F.M.; SANTOS, R.C. Avaliação da eficiência de inseticidas em função dos tipos de danos ocasionados pelo bicudo-do-algodoeiro, Anthonomus grandis Boheman, 1843 (Coleoptera: Curculionidae). Anais da Sociedade Entomológica do Brasil, Londrina, v.21, n.3, p.401-411, 1992.

SAMPAIO, I.B.M. Estatística aplicada à experimentação animal. Belo Horizonte: Fundação de Ensino e Pesquisa em Medicina Veterinária e Zootecnia, 1998. 221p.

SOARES, J.J.; ARAÚJO, A.D. Influência da época de plantio e do ataque do bicudo Anthonomus grandis (Coleoptera: Curculionidae) sobre a abscisão de botões e maçãs de algodoeiro. Anais da Sociedade Entomológica do Brasil, Londrina, v.22, n.2, p.251-257, 1993.

SOARES, J.J.; LARA, F.M.; SILVA, C.A.D.; ALMEIDA, R.P.; WANDERLEY, D.S. Influência da posição do fruto na planta sobre a produção do algodoeiro. Pesquisa Agropecuária Brasileira, Brasília, v.34, n.5, p.755-759, 1999.

STERLING, W.L.; ADKINSON, P.L. Seasonal biology of the boll weevil in the High Plain and Rolling Plains of Texas as compared with previous biological studies of this insect. Texas: Texas A\&M University, Texas Agricultural Experiment Station, 1971.12p. 